\title{
SOME MISCELLANEOUS ASPECTS OF SECTION 15 OF THE CANADIAN CHARTER OF RIGHTS AND FREEDOMS*
}

\author{
GERALD L. GALL**
}

\begin{abstract}
Professor Gall reviews various unrelated aspects of s. 15 of the Charter. Included in the article are discussions of s. 15 and its relation to other Charter sections (ss. 27 \& 28), the possibility of re-arguing pre-1985 Charter cases in the context of s. 15 , and the effect of s. 15 on other parts of the Constitution and non-constitutional instruments. The author notes that s. 15 has as its basis the concept of "rule of law".
\end{abstract}

\section{THE PREAMBLE}

Given that virtually all interpretation acts state that a preamble forms part of a statute, then it follows that the Preamble to the Charter is an integral part of its make-up. The Preamble states that "Canada is founded upon the principles that recognize . . . the rule of law."

Dicey wrote in his Introduction to the Law of the Constitution, in its tenth edition edited by Professor E.C.S. Wade, that the rule of law consists of several components, one of which is:'

[E]quality before the law, or the equal subjection of all classes to the ordinary law of the land, administered by the ordinary law courts; the "rule of law" in this sense excludes the idea of any exemption of officials or others from the duty of obedience to the law which governs other citizens or from the jurisdiction of the ordinary tribunals. . . .

Professor H. W. Jones re-stated the Dicean definition, in the modern context, to mean: ${ }^{2}$

All members of society, private persons and government of ficials alike, must be equally responsible before the law.

Commenting on this Dicean definition, Professor Tarnopolsky (as he then was) states as follows: ${ }^{3}$

A more modern, although somewhat closely related variant of the Dicey definition of "equality before the law", is that suggested by Marshall, i.e., that the doctrine implies "equality of state and individual before the law". Although Marshall acknowledges that since the state imposes its will upon the individual, the state and citizen cannot really be equals, and while state servants might in fact be given specific powers, nevertheless, the doctrine requires that rules granting powers to of ficials should be precise, and that it is the duty of the courts to hold an equal balance between citizens and officials.

Mr. Justice David McDonald stated in an unpublished paper prepared for delivery at a Seminar of Judges of the Provincial Court of Saskatchewan that, having regard to the Dicean view of rule of law, "the general language of s. $15(1) \ldots$ probably demands a broader notion of equality" than that contemplated by Dicey. No doubt he is correct. In support of his view, consider, for example, the following views.

Again, Professor Tarnopolsky comments on the narrow application of the Dicean notion of rule of law:4

- This article was presented at a series of seminars on s. 15 of the Charter sponsored by the Friends of the Faculty of Law.

*. Professor of Law, University of Alberta.

1. Tarnopolsky and Beaudoin, Canadian Charter of Rights and Freedoms: Commentary (1982) $399-400$.

2. See Tarnopolsky, The Canadian Bill of Rights (2nd ed. 1975) 120.

3. Supra n. 1 at 400 .

4. Id. at $400-01$. 
Some of Dicey's modern critics, for example Sir Ivor Jennings, have extended this concept somewhat, to require a basic procedural equality in the sense that there shall be impartiality before the ordinary law courts as well as other adjudicatory tribunals. Sir Ivor described "equality before the law" thus:

It assumes that among equals the laws should be equal and should be equally administered, that like should be treated alike. The right to sue and be sued, to prosecute and be prosecuted, for the same kind of action should be the same for all citizens of full age and understanding, and without distinction of race, religion, wealth, social status or political influence.

Professor Claire Beckton of the Faculty of Law of Dalhousie University offers the following thoughts in an unpublished paper prepared for the Canadian Human Rights Foundation:

... it is important to say a few words about the meaning of equality. There is no universally accepted definition of equality in Canada. However, there do seem to be some accepted general premises. The first is that equality requires the recognition of the equal dignity and worth of all individuals . . . therefore, no one should be denied opportunities for reasons unrelated to their ability, such as race and sex, because that implies a variation in the worth of individuals. However, equality does not mean treating everyone in the same way for all purposes. Sometimes equality means treating a person differently because of his or her differences .... it must also be recognized that the laws cannot function without making distinctions. What becomes significant is the nature of the distinctions and the justification for using them. . . . Equality must also be real and not pro forma. This principle has only evolved in the past century, and more specifically in the past few decades. A.V. Dicey equality in 1885 , in his Introduction to the Study of Constitutional Law, he stated that equality before the law entailed "the equal subjection of all classes to the ordinary law ... of the land as administered by the ordinary courts". All members of society were to be governed by the rule of law.

\section{Professor Beckton cites the Lavell ${ }^{s}$ case as illustrative of the Dicean} principle in action and then concludes:

... the principle of "equality of treatment in the enforcement and application of the laws of Canada before the law enforcement authorities and the ordinary courts of the land". However, this approach was considered unacceptable and groups and individuals who appeared before the Special Joint Parliamentary Committee on the Constitution in 1981 argued for wording in section 15 that would ensure a requirement not only of procedural equality but also of substantive equality.

These excerpts are provided to show, first, that the $\mathrm{s} .15$ language chosen is a deliberate attempt to go beyond Dicey. However, notwithstanding this, whatever is contemplated by the language of $s .15$, its origin can be traced, in our Anglo-Canadian tradition, to the Dicean notion of rule of law. This view, of course, is buttressed by the specific incorporation of rule of law as part of the Charter's Preamble. Commenting on the importance of the words in a preamble, Professor Tarnopolsky stated as follows: ${ }^{6}$

It should be noted that in our constitutional history the preamble to the B.N.A. Act has proved very important. Although our constitution makes no reference to the most important and fundamental characteristics of our constitution, like responsible government, the existence of political parties, the position of the Prime Minister and his cabinet, or the role of the Leader of the Opposition, all of these elements of our constitution are acknowledged as deriving from a clause in the preamble to the B.N.A. Act which refers to the constitution as being "similar in Principle to that of the United Kingdom". Also it should not be forgotten that this same preamble, resorted to as one of the reasons given by several Supreme Court Justices for declaring the Alberta Press Bill invalid, and subsequently in restraining the Quebec Government of Maurice Duplessis in his battle with the Jehovah's Witnesses and Communists, which has provided us with some of our most important civil liberties cases. Thus, the importance of a preamble, or an "aims" clause, cannot be minimized.

5. [1974] S.C.R. 1349.

6. Supra n. 1 at 441. 
The significance, therefore, of the foregoing is as follows:

1. The meaning of s. 15 has at its core the Dicean notion of rule of law, although; as Mr. Justice McDonald says, s. 15 probably goes much further. This is somewhat analogous to regarding fairness as the core matter of natural justice in administrative law.

2. The language of $\mathbf{s} . \mathbf{1 5}$ specifically invites an interpretation of the section that relates to both substance and procedure and not only to procedure as suggested by the Dicean notion of rule of law.

3. Notwithstanding the plea of academics, judges, and others that invoke the use of American jurisprudence in interpreting s. 15 (and they are all probably right in so doing in order to give s. 15 its intended expansive scope), we must not lose sight of British roots in looking at the meaning of equality. The Preamble, demands this of us just as the Preamble to the old B.N.A. Act (Constitution Act of 1867), containing the so-called "implied Bill of Rights" in the Constitution, required us to recognize the doctrines of rule of law, parliamentary sovereignty and responsible government as integral features of our Canadian constitutional system.

\section{THE SUBSTANTIVE SECTIONS OF THE CHARTER}

In the years between the coming into force of most of the Charter and the coming into force of s. 15 , many cases dealt with issues which, conceivably, could have been s. 15 issues. Big $M^{7}$ was concerned with freedom of religion under s. 2 but it could have been argued on the basis of religious discrimination under s. 15. Skapinker ${ }^{8}$ was a s. 6 case but it could have a s. 15 case argued on the basis of discrimination based upon national origin. As it turns out, it was in fact so argued in the case of Andrews v. Law Society of British Columbia.' In that case, Mr. Justice Taylor of the Supreme Court of British Columbia makes reference to the Skapinker case: ${ }^{10}$

But the challenge made in Skapinker - an unsuccessful attack on a citizenship requirement contained in the equivalent Ontario statute - was based on the guarantee of "mobility rights" under s. 6(2)(b) of the Charter. Section 15 was not then in force. . .

First, Mr. Justice Taylor reviews what happened in the Skapinker decision:"

In the Skapinker case, supra, Grange J. A., giving judgment for the majority in the Ontario Court of Appeal (1983), 145 D.L.R. (3d) 502, took the view that the "mobility rights" guaranteed by s. 6 of the Charter extend the right to pursue the gaining of a livelihood to persons who remain resident within one province as well as to those who move to one province from another. On that ground, the majority declared invalid a provision of the equivalent Ontario statute which restricts the practice of law in the province to "Canadian citizens or other British subjects". The Supreme Court of Canada reversed that decision, holding that $\mathrm{s.} 6$ rights do not apply to permanent residents of a province, and the Supreme Court did not have to consider certain observations which were made in the Ontario Court of Appeal on the merits of the citizenship requirement.

7. [1985] 3 W.W.R. 481 (S.C.C.).

8. (1983) 145 D.L.R. (3d) 502 (Ont. C.A.).

9. (1985) 66 B.C.L.R. 363.

10. Id. at 365 .

11. Id. at 371-72. 
Mr. Justice Taylor then reviews the same issue in terms of the s. 15 argument: ${ }^{12}$

I conclude that the question raised in this case under s. 15 is whether restriction of entry to the legal profession in this province to Canadian citizens discriminates against certain classes of non-Canadian candidates earlier described by irrationally imposing a distinction based on a personal characteristic which is irrelevant to the practice of law or carries consequences which cannot reasonably be justified in relation to the relevance of that characteristic in that context. ... I think it understandable in Canada, which is both a country based, as the preamble to our Charter emphasizes, on the rule of law and a federal state in which the courts must review the work of the elected legislators, that there should be a desire that those engaged in the legal process be themselves citizens. . . . I conclude that the requirement contained in s. 42 of the Barristers and Solicitors Act constitutes neither denial of equality under the law nor discrimination, within the meaning of $s .15$ of the Charter.

On appeal the citizenship requirement was in fact struck down as being violative of s. 15. ${ }^{13}$ Just as in the Andrews case, almost every, and if that is an exaggeration, at least most of the pre-1985 Charter cases could now be re-cast as $\mathbf{s .} 15$ cases. The significance of this is as follows, first, in addition to all of the vast number of $\mathrm{s} .15$ issues yet to be dealt with, some of the old issues, in these early cases, may now be re-argued, for new litigants, in the context of s. 15. If some of these old cases are still with us, now under appeal, conceivably, the s. 15 argument may now be invoked to buttress or serve as an alternative to the earlier argument for purposes of the appeal.

An example of the former possibility was seen in the case of Mahe v. The Queen. ${ }^{14}$ In an earlier Ontario case, reference Re Education Act of Ontario and Minority Language Education Rights, ${ }^{15}$ with virtually identical facts as in Mahe, the Ontario Court of Appeal briefly considered s. 15, even in the absence of it having come into force. The court stated: ${ }^{16}$

In the light of s. 27 , s. $23(3)(b)$ should be interpreted to mean that minority language children must receive their instruction in facilities in which the educational environment will be that of the linguistic minority. Only then can the facilities reasonably be said to reflect the minority culture and appertain to the minority.

Although s. 15 was not referred to in argument on this point and is not yet in force, a perusal of it tends to support our conclusion.

In the Mahe case, referred to above, s. 15 was, in fact, argued before $\mathrm{Mr}$. Justice Purvis; however, the Judge decided not to avail himself of the s. 15 possibility. Justice Purvis simply states: ${ }^{17}$

The plaintiffs argued that $s .15$ of the Charter, the equality rights section which came into effect April 17, 1985, gave strength to their claim.

I do not agree with that submission. The right to minority language instruction in Canadian schools is restricted to French or English minorities in s. 23. It is a specific and limited statement of rights. The general statements in s. 15, which makes no mention of education or minority language instruction, should not be permitted to change the specific matters dealt with in s. 23.

Consider also the case of Paquette v. The Queen ${ }^{18}$ when Mr. Justice Sinclair makes the following remarks:

12. Id. at 373-76.

13. Unreported, 12 May 1986, CA004797 (B.C.C.A.).

14. (1985) 39 Alta. L.R. (2d) 215 (Alta. Q.B.) (now under appeal).

15. (1984) 10 D.L.R. (4th) 491.

16. Id. at 529 .

17. Supra n. 14 at 240.

18. (1985) 40 Alta. L.R. (2d) 38 at 69-70. 
An argument is raised in the written submission of the applicant based upon s. $15(1)$ of the Canadian Charter of Rights and Freedoms. The argument concerns the effect of s. 462.1 of the Criminal Code.

The point is not dealt with in the written submissions of the Attorneys General for Canada and Alberta. Nor did counsel for the applicant have much opportunity to deal with it during oral argument on 13th and 14th May. Indeed, counsel for the Attorney General for Canada said at the time that if $\mathrm{s}$. 15 were to become a serious issue he might ask leave to submit further argument. ...

In these circumstances counsel were consulted as to whether judgment on the issues dealt with in the present reasons should be delivered immediately or further reserved until the effect of $\mathrm{s}$. 15 has been considered. I have come to the conclusion that the administration of justice would best be served if the present reasons were issued now.

If the applicant wishes to continue his application under s. 15, written notice to that ef fect must be filed with the clerk of the court, and served on counsel for the Attorneys General, no later than 30th August 1985. In that event, I would ask counsel to consult with me within 15 days thereafter so that an early date for the resumed hearing may be established. Should the applicant decide not to continue with the application, any party may elect to prepare and enter formal judgment.

In fact, the applicant did elect to continue his application under s. 15. In the result, Mr. Justice Sinclair held that Mr. Paquette was entitled to have all aspects of his trial in Alberta conducted in the French language, such entitlements conferred in part because of early statutory provisions and in part because of s. 15. ${ }^{19}$ The opposite result occurred in Black v. Law Society of Alberta ${ }^{20}$ when the Alberta Court of Appeal took this position:

This is a ruling on an application made at the opening of the appeal. The appellant sought leave to amend the statement of claim to plead the equality provisions of $s .15$ of the Charter of Rights.

It is manifestly clear to us that the argument requiring the consideration of ss. 15 and 1 of the Charter simply cannot be entertained at this level without the matter having passed through the trial process. It is clear from the argument presented that the parties must address questions of fact including some questions of "societal" facts. Some fact issues were canvassed at trial but not in the context of s. 15. We therefore cannot allow the amendment.

In considering the above examples, it is important to note that they do not really concern themselves with the related issue of the retrospective application of s. 15. That is a different matter which is not dealt with in this paper.

In any event, it is also conceivable that many Charter arguments will be based, not on s. 15 alone, but on the basis of s. 15 together with or as an alternative to or as an aid in the interpretation of other substantive sections of the Charter. In this regard, Mr. Justice McDonald, in the unpublished paper referred to earlier, raises this possibility in connection with various provisions of the Charter. For example, he suggests that $s .10$ rights might themselves have to be interpreted in such a way so as to not violate the protections given in s. 15. For example, he states:

S. 15 creates an autonomous right, and also, implicitly, overlies all other substantive sections. That is, the interpretation of all other sections must not violate the imperatives of s. 15.

Here are some possible illustrations of this aspect of s. 15:

1. In deciding whether the police have complied with the s. 10 (b) duty to advise a person arrested or detained of his right to retain and instruct counsel without delay, the court may impose a more exacting standard in the case of a person who suffers from an evident mental disability if that disability is in the nature of being of low intelligence.

19. (1986) 43 Alta. L.R. (2d) 97.

20. (1985) 38 Alta. L.R. (2d) 109 at 109-10. 
The court may in such a case expect the policeman to use simple language, even to ask the arrestee or detainee to explain what it is he understands by the advice. It may not be good enough in such a case to accept the assurance of the policeman that the person understood.

2. The same reasoning would apply to the s. $10(a)$ duty to inform the arrestee or detainee promptly of the specific of fence with which he is charged. The court may expect the policeman, once he realizes that he is dealing with a person of seriously sub-normal intelligence, to do his best to explain the charge in terms that the person will understand.

3. Looking again at s. 10(b), the court may expect the police to be of greater assistance to a person of evidently sub-normal intelligence to get in touch with a lawyer, than they may be expected to do in the case of a normal person.

4. The court may consider that it is clearer that an accused of sub-normal intelligence cannot have the "fair hearing" demanded by s. 10(d) if he lacks counsel, than if the accused were not suffering from a mental disability.

\section{REMEDIES}

Section 15 provides for both an opportunity and a dilemma for the courts, from the point of view of remedies. Aside from the traditional remedies and the new remedies seen in the first four years of Charter experience, s. 15, through the instrumentality of s. 24(1) and to a lesser extent s. 52(1), is the section most likely to provide the courts with the opportunity to order U.S.-style bussing-like remedies in order to redress an inequality of serious magnitude. Many students of Canadian constitutional law often refer to the tradition of Canadian judicial conservatism to deny the likelihood of U.S.-style remedies. However, it is becoming clear that the Supreme Court of Canada is taking an activist role in dealing with constitutional matters. For example, consider the decision of the Supreme Court of Canada in Reference Re Language Rights ${ }^{21}$ in Manitoba where the Supreme Court ordered the translation of all Manitoba laws into French within a designated period of time. In effect, in that case, the Supreme Court ordered specific legislative action in accordance with a judicially-dictated timetable as a remedy to effect a constitutional result. In essence, the remedy was political action, in the nature of legislative change. If that is possible, and it clearly is, the ordering of executive action (which would more closely simulate a U.S.-style bussing decree) is, therefore, also within the realm of possibility as an appropriate remedy to effect a constitutional result. That is, in short, the opportunity available to our courts. The dilemma, under either s. 24(1) or s. 52, relates to a situation in which the only appropriate remedy might result in an injustice in an instant case. Specifically, one might refer to those cases recently where judges have struck down gender-specific sections of the Criminal Code as violative of s. 15. The result has been that some male persons who have allegedly committed certain sex offences have escaped liability when the particular gender-specific sections under which they have been charged have been struck down as the only remedy available to the court, given Parliamentary inaction to remedy the situation, in order to secure compliance with s. 15 . See R. v. D.I.L. ${ }^{22}$ and $R$. v. Neely. ${ }^{23}$

21. [1985] 4 W.W.R. 385.

22. (1985) 46 C.R. (3d) 172 (Ont. Dist. Ct.).

23. (1985) 7 C.R.D. 350.70-02 (Ont. Dist. Ct.). 


\section{MULTICULTURAL RIGHTS - THE RELATION OF SECTION 27 TO SECTION 15}

\section{Mr. Justice Tarnopolsky has written in the past that multicultural rights are a particular kind of equality right. He has stated that, ${ }^{24}$}

The first thing that can be noted about $\mathrm{s} .27$ is that it is impossible to visualize what a court could grant pursuant to that section alone. Section 27 is a purely declaratory or interpretive provision. It has to be seen as being somewhat similar to a preamble or an "aims" provision, which are not legally binding in the narrow sense. Nevertheless, such provisions do have great psychological value in giving a government and the people "the broad directions in which they are going" (Molgat-MacGuigan Report). . . .

The most important provision in respect to which s. 27 could have effect is s. 15. For the most part, of course, subs. 15(1) does not require the aid of $s .27$ to provide protection because of one's race, national or ethnic origin, or religion. However, it is possible to envisage that with respect to one of the equality clauses, i.e., "equal benefit of the law", a claim could be made for equal benefits of grants for cultural activities. Individuals who belong to a cultural group which does not receive grants equivalent to those received by other cultural groups, might be able to invalidate the giving of disproportionate grants to such more fortunate groups. Although it is impossible to envisage a court being prepared to order a government as to whether such money should be spent, or how much should be expended, nevertheless, if grants are made pursuant to laws which do not meet the test of "equal benefit" with respect to race, national or ethnic origin, or religion, then invalidation might be sought.

Furthermore, although subs. 15(2) does not provide for a right to compel the adoption of an "affirmative action program", to the extent that affirmative action programmes are adopted, it may be possible to use s. 27 as an argument that groups of certain racial or national or ethnic origins should not be left out of consideration. Again, this would appear to be a basis for an argument based upon persuasion of legislatures, rather than of courts.

Professor Beckton, in the unpublished paper referred to earlier, also addresses this issue. In particular, she states:

Section 15 is one of the most important guarantees in the Charter for the purposes of the protection of the multicultural heritage of Canadians. The wording of section 15 can be interpreted so as to prevent discrimination while still allowing for distinctiveness among groups of individuals. There is often a fine line between discrimination and recognition of the uniqueness of cultural values and section 15 must be interpreted to facilitate both. Section 27 is an important statement of principle which must be read with section 15 to ensure that the guarantee of equality is interpreted in a manner consistent with the preservation of multicultural values. ... It is interesting to note that section 15 uses the term "individual" when specifying the entitlement. Yet, when dealing with issues of multiculturalism in section 27 , it can be argued that the entire concept of multiculturalism is premised upon a form of group or collective rights; it seems to focus upon the values shared by a group. How then can section 15 and section 27 be reconciled?

The Charter clearly recognizes several rights that could be classified as collective. Language rights in section 16 to 22 of the Charter may be considered to be collective rights, although they are often asserted by individuals. ...

... While section 15 seems to place an emphasis on individual rights, it is clear that it must be read together with group rights whose purposes are generally the protection of Canada's multicultural heritage.

Subsection (2) of section 15 is an important provision. . . . This provision was inserted to ensure that programs designed to benefit those disadvantaged from past discrimination would not be labelled as "reverse discrimination", a problem faced by the United States courts because their equal protection clause includes no such provision. It enables governments to implement affirmative action programs without entailing the risk of engaging in unconstitutional activities. This may have significant ramifications for the preservation of multiculturalism, since it may be necessary to provide special measures for some groups to ensure retention of their cultural heritage and to overcome 
disadvantages arising from past discrimination. It is conceivable that the courts could read section 15(2) and section 27 together to permit special programs aimed at assisting a cultural group retain its distinctiveness.

Professor Beckton raises three specific issues in relation to the interaction between ss. 27 and 15. First, she addresses the minority language education issue:

Is it discriminatory to provide education in French and English, but not in Japanese? Can the unique status of the founding cultures be used as a justification? Apart from section 27 it may be possible to rely on the guarantees of two official languages in section 16 to give priority to French and English linguistic minorities.

But will this preclude the government from funding the teaching of other minority language? If funding is provided for Ukrainian and Chinese, must it be provided for all such minority linguistic groups? ...

To determine if funding of one non-official linguistic group as opposed to a second one contravenes section 15, a number of factors may have to be considered. Since equality does not mean treating everyone the same, the very fact of funding will not in itself be a denial of equality. Funding may be necessary for some groups but not others. In addition, the amount of funding may vary with the size and needs of the groups.

Secondly, Professor Beckton discusses the question of government funding of cultural groupings:
A similar question arises with respect to multiculturalism policy and funding of cultural groups. Section 15 and section 27 do not require funding of any groups, but if funding is provided, equality issues could arise. In many instances funding is provided for specific purposes which could influence the selection of funding recipients and amounts. If a Chinese-Canadian association receives funding to establish a museum, this would not necessarily imply a requirement that a Greek-Canadian association receive similar funding, although in some instances it may be necessary to justify the distinction.

In addition, Professor Beckton addresses the issue of adoptions as it relates to multiculturalism and equality:

[Another] example of a multiculturalism and equality issue arises in the context of adoptions, as mentioned above. Currently adoption agencies may have a policy of permitting adoption only by parents of a religious belief similar to that of the child, or of giving such parents preference. Is this a denial of section 15 guarantees? It can be argued that this raises a section 27 issue, because there may be an argument for retention of Canada's multicultural heritage. At the same time, there is an issue of the rights of the adopting parents and the best interests of the child.

Are the adopting parents discriminated against because they are not of the cultural or linguistic group into which the child was born, since it is not the beliefs of the child that are at issue? This issue is particularly sharp when it is a racial group which argues against adoption of its members by non-members of the race. Will that be a denial of equality, or merely preservation of cultural values?

\section{Professor Beckton concludes her paper as follows:}

... section 27 is a new guarantee. It is clear, however, that section 15 and section 27 must be read together to ensure that equality does not mean sameness, while at the same time preservation of multicultural values is not used as an excuse for discrimination. Examination of the social and economic context of any equality claims will be essential to ensure that section 15 and section 27 are used to ensure equality and cultural uniqueness. Section 15(2) may be very significant in the context of our multicultural heritage. It permits programs designed to ameliorate the conditions of disadvantaged groups. It could permit programs to enhance the culture of groups, such as aboriginals, whose culture may be endangered by past and present discrimination.

There are at least three observations to be made in respect of the remarks set out above. First, the application of $\mathrm{s.} 27$ is necessarily limited by its own words to an adjectival role. It might serve to modify or even provide a wider scope in the interpretation of other Charter rights, but it does not confer any rights in and of itself. Secondly, notwithstanding the foregoing, 
it is within the realm of possibility that should s. 33 ever be invoked to render legislation immune from the application of s. 15 , one is still left with s. 27. Under s. 33, governments cannot opt out of s. 27. Therefore, in that event, $\mathrm{s.} 27$ might be interpreted by a court in a substantive manner to give effect, in the absence of $\mathrm{s}$. 15, to equality rights in the multicultural context. That is highly speculative and frankly doubtful but the possibility exists. Finally, one should not lose sight of the fact that $\mathrm{s} .27$ protects what is essentially a group right. Its reference to the multicultural heritage of Canadians confers a protection applicable to cultural groupings. On the other hand, the substantive rights conferred elsewhere in the Charter are essentially individual rights. As Professor Tarnopolsky (as he then was) points out, one often seeks to advance an individual right arising out of one's membership in a group entity but it is nonetheless an assertion of an individual right. Perhaps the best example of this is freedom of religion in s. 2. One might assert freedom of religion in a particular case. Moreover, such an assertion can only be made because of one's membership in a religious grouping, nonetheless, it is still an assertion of an individual right by a particular applicant. As a result, it is unlikely that a group right section, namely s. 27, would aid in the interpretation of an individual right as found under most of the other sections of the Charter. This would therefore seem to suggest that s. 27 has a narrow ambit. Mr. Justice Tarnopolsky, in Videoflicks, ${ }^{25}$ seems to have modified his view of this issue, but it still remains a problem to be dealt with by the courts. There are of course some group rights sections in the Charter, namely, the minority language education rights and the linguistic rights, but by and large the Charter is an individual rights document with s. 27 advancing protections to cultural groupings rather than to individuals.

\section{SECTION 28}

Section 28 states:

Notwithstanding anything in this Charter, the rights and freedoms referred to in it are guaranteed equally to male and female persons.

Again, Mr. Justice Tarnopolsky and others have lumped s. 28 with ss. 27 and 15 to comprise the equality rights package in the Charter. By its own wording, s. 28 is also an adjectival section. It refers to the manner in which other rights ought to be interpreted. It does not, on its own, confer any substantive rights.

In a chapter entitled "Sexual Equality: Interpreting Section 28", appearing in Bayefsky and Eberts, Equality Rights and the Canadian Charter of Rights and Freedoms ${ }^{26}$ Professor Katherine J. de Jong provides a thorough examination of the contextual framework of s. 28 and concludes essentially that to read s. 28 literally would lead to the conclusion that s. 28 is "little more than a guide to the application of the Charter". Moreover, to interpret s. 28 literally would be to ignore "in almost total isolation ... the context in which it was enacted". Instead, she argues, that

25. (1984) 48 O.R. (2d) 395 (Ont. C.A.) (under appeal to the S.C.C.).

26. (1985) 493. 
at "a minimum section 28 states that both males and females are legal persons". ${ }^{27}$ Moreover, Professor de Jong asserts: ${ }^{28}$

The legislative history makes it clear that section 28 was not intended to be a "queer" or

"meaningless" provision. It takes its meaning in part from the popular understanding of how the legal system restricted women's legal rights in the past, and the resulting determination to ensure that such legal distinctions between the sexes would be impossible in the future. . . .

Section 28 , interpreted substantively, is a prohibition of differentiation on the basis of sex made with respect only to the rights and freedoms referred to in the Charter. This means that the principle of sexual equality set out in section 28 forms a substantive part of each right and freedom referred to in the Charter, including the rights of equality before and under the law in section 15 .

Professor de Jong then analyzes the introductory words of s. 28, namely, the phrase "notwithstanding anything in this Charter". In so doing, she reaches the following conclusions, among others. First, those words are particularly applicable to ss. $1,15,25,27$, and 33 and suggest that "no other section [of the Charter] limits the effect of s. 28". Secondly, the notwithstanding word in s. 28 and its relation to the words " anything in this Charter" in the section makes the notwithstanding formulation broader in s. 28 than it is in s. 33, thus giving s. 28 "at least the same priority . . . as a s. 33 override". Thirdly, the guarantee of equality in s. 28 operates prior to any restriction under s. 1 . That is to say, "[s]ection 28 permeates the Charter to supplant the reasonableness standard adopted in section 1 whenever the rights and freedoms it is being applied to are enjoyed unequally on the basis of sex." 29

A plain examination of the wording seems to suggest that insofar as the relation of ss. 28 to 33 is concerned, since s. 28 operates "notwithstanding anything in this Charter", the override or opting out provision in s. 33 cannot be invoked or applied to another section of the Charter in such a way as to deny sexual equality. This is probably a contentious assertion because it depends upon an acceptance of the above view of the grammatical construction and presupposes that the intent of the drafters in including the precise language of s. 28 was designed to achieve this result.

Finally, the issue has come up, from time to time, whether the provision of sexual equality in s. 28 serves to emasculate the possibility of affirmative action on the basis of sex in s. 15(2). Professor de Jong denies this possibility: ${ }^{30}$

Section 28 simply ensures that defining a legitimate affirmative action program and the standard of review on which it is based, are interpreted and applied equally to male and female persons. This means that a court cannot apply a standard of review to a program designed to benefit females which was different from the standard of review applied to programs designed to benefit males.

To some extent, this view is supported by Professor Tarnopolsky (as he then was): ${ }^{31}$

. . . if s. 28 provides that "notwithstanding anything in this Charter" the rights and freedoms "are guaranteed equally to male and female persons", what would be the

27. Id. at 517 .

28. Id. at 518 .

29. Id. at 525.

30. Id. at 527.

31. Supra n. 1 at 436. 
constitutional validity of an affirmative action program favouring woman? The answer unquestionably must be that such programs must be valid. In the first place, it would be impossible to ignore the clear historical fact that s. 28 was enacted in order to escape the possibility of applying s. 1 so as to "justify" discrimination against women, or s. 33 so as to totally exempt discriminatory statutes. Second, subs. 15(2) is evidently only an explanation of the substantive provision, which is subs. 15(1). It is subs. 15(1) which provides for the right of equality and which is reaffirmed in $\mathbf{s .} 28$ as having always be applied equally to men and women. Subsection (2) merely defines that "affirmative action programs" do not constitute infringement of subs. (1). Subsection (2) does not in itself provide for a right, but is merely an amplification of what the right includes.

On the other hand, Professor Wayne MacKay of Dalhousie University, in a paper delivered to judicial seminars in Atlantic Canada, raises the possibility that s. 28 might affect the application of s. 15(2) in respect of affirmative action programs based on sex. He says that on "a strict literal interpretation he would have the ironic and perverse result that woman would be excluded from affirmative action programs"'. However, after raising the possibility, Professor MacKay then gives cogent reasons denying the possibility. Professor MacKay also raises the possibility that the notwithstanding clause in $\mathrm{s} .28 \mathrm{might}$ limit the scope of the override in s. 33.

\section{THE RELATIONSHIP OF SECTION 15 TO OTHER PARTS OF THE CONSTITUTION AND TO OTHER NON-CONSTITUTIONAL INSTRUMENTS}

Essentially, we have now in place layer upon layer of human rights legislation. Provincially, in Alberta, we have a bill of rights, an antidiscrimination statute, an ombudsman statute, while federally, we also have a bill of rights, an anti-discrimination statute and several ombudsman statutes. In addition, we have the application to Canadian law of the U.N. Covenants on Economic, Social and Cultural Rights, and or Political and Civil Rights and the Optional Protocol to the latter. Therefore, it is not surprising that there will be interaction between these various instruments to protect human rights and the Charter. In addition to these human rights instruments, one should be aware of various legislative initiatives that are likely to be brought about as a result of certain recent commissions and committees of inquiry related, broadly speaking, to equality concerns. First, one might refer to the so-called Daudlin Committee of the House of Commons on Visible Minorities. The Daudlin Committee made certain recommendations some of which might eventually materialize in legislation. Secondly, one should refer to the Abella Commission. Judge Abella's recommendations in connection with employment equity has specifically led to Bill C-62, recently enacted by Parliament. Bill C-62 requires various federal agencies to comply with a reporting requirement to a central agency as to their hiring practices. The object is to ensure that more women and disabled persons take their rightful place in the working environment. Many have criticized Bill C-62 as relatively weak legislation, only going part of the way in the implementation of the Abella recommendations. In addition, some provinces, most notably Manitoba, have proposed (and in the case of Manitoba, passed) similar legislation. Finally, one should refer to the Boyer Committee (i.e. the Parliamentary Committee on Equality Rights) which received its mandate in early 1985 to make recommendations to ensure that all federal laws conform to the requirements of $s .15$ of the 
Charter. That committee has now reported (see "Equality for All"). The federal government tabled proposals for consequential legislation. Similar reviews have been done provincially, for example in Alberta, a provincial government statute audit has lead to several amendments of various laws, including some important amendments to the Individual's Rights Protection $\mathrm{Act}^{32}$ in June of 1985. One of those amendments relates to the inclusion of pregnancy as a prohibited ground of discrimination and a second re-defines age as eighteen or over under the I.R.P. Act (instead of the pre-June definition of between the ages of 45 and 65). In any event, there is a significant amount of legislative activity which is designed to ensure compliance with the requirements of s. 15 and to avoid, in a preventative way, $\mathrm{s} .15$ challenges in Court.

There are also some miscellaneous points concerning the relationship of non-constitutional human rights instruments to the Charter. First, although s. 32 is not the subject of this paper, one might, nonetheless, briefly refer to the issue as to whether s. 32 makes the Charter applicable to the private sector, in the context, however, of the provisions of s. 26. Section 26 states that:

The guarantee given in this Charter of certain rights and freedoms shall not be construed as denying the existence of any other rights or freedoms that exist in Canada.

One view of this section is that it seems to buttress the argument that, in fact, the Charter does not apply to the private sector. It could be argued that $s .26$ envisages the existence of other, non-constitutional legislation designed to protect human rights, both federally and provincially. It suggests that there is a complementary scheme. That scheme would provide public sector protection of human rights arising out of the provisions of the Charter (s. 32) and private sector protection of human rights arising out of the provisions in regular legislation (s. 26). One should realize, of course, that the public sector is also covered in the nonconstitutional legislation, but why else would s. 26 have been included, if not to recognize that there are other protections, in the private sector, which would serve to complement the public sector protections of the Charter. Secondly, one has to recognize the possibility that some nonconstitutional protections of human rights might themselves violate the provisions of the Charter. For example, before the June, 1985 amendment of the Individual's Rights Protection Act to alter the definition of age, arguably, that statute violated s. 15 of the Charter. And there might be other instances where a similar argument may be invoked. Thirdly, the courts might be assisted in identifying the unenumerated grounds in s. 15 by examining some of the enumerated grounds in the provincial antidiscrimination statutes. These enumerated grounds could serve as potential candidates for becoming unenumerated grounds under the Charter. For example, under Prince Edward Island anti-discrimination legislation, political belief or opinion is an enumerated ground.$^{33}$ Its inclusion in the P.E.I. statute raises the likelihood that it might potentially become an unenumerated ground under the Charter.

32. R.S.A. 1980 , c. I-2, as am. S.A. 1985 , c. 33.

33. Human Rights Act, S.P.E.I. 1975, c. 72, s. 13 as am. S.P.E.I. 1980, c. 26 , s. 3. 
To conclude, there is one final, but nonetheless important, issue. And that is the relationship of the Charter to other sections of the Constitution. First there is the possibility that some rights are protected both in the Charter and outside of the Charter, with a given argument being supported by reference to both sources. For example, there are aboriginal rights in the Charter and, in addition, there is a Part of the Constitution Act of 1982, outside of the Charter, which deals specifically with aboriginal rights. There are other rights in the Charter, perhaps s. 2 rights, which might be supported by the invocation of, for example, the implied Bill of Rights in the Preamble to the Constitution Act of 1867. There are probably other examples as well. The real problem relates to conflict situations where one section of the Charter conflicts with another section of the Constitution either inside of or outside of the Charter. Presumably, if that should occur, the basic principles of statutory interpretation would apply in order to resolve the conflict. For example, a court might invoke principles of statutory interpretation which hold that a later statute overrules an earlier statute to the extent of an inconsistency or that a more specific provision takes precedent over a general provision, etc. To a minor extent, one such situation has already arisen. That is the case of Addy v. The Queen, ${ }^{34}$ a decision of the Trial Division of the Federal Court of Canada. In that case, essentially two separate issues arise. Mr. Justice Addy is a Judge of the Federal Court. The Federal Court Act ${ }^{3 \mathrm{~s}}$ requires that Judges of that Court must retire at age 70. The constitutional authority for the Federal Court Act is s. 101 of the Constitution Act of 1867. Section 101 states that:

The Parliament of Canada may, notwithstanding anything in this Act, ... provide for ... the Establishment of any additional Courts for the better Administration of the Laws of Canada.

Mr. Justice Addy's first argument is that s. 8(2) of the Federal Court Act which requires judges of the Federal Court who were appointed on or after June 1,1971 to retire at age 70 is inconsistent with s. 99(2) of the Constitution Act of 1867. The latter section requires the judges of the Superior Courts to hold office until age 75. The issue then becomes whether the Federal Court, established under the authority of s. 101, is a Superior Court within the meaning of that term in s. 99(2). If it is a Superior Court then the provisions of s. 8(2) of the Federal Court Act would conflict with s. 99(2) of the Constitution Act of 1867. If however the Federal Court is not a Superior Court within the meaning of s. 99(2), there is no conflict. Mr. Justice Grant, a Deputy Judge of the Federal Court, held that, for various reasons, the provisions in s. 99(2) applied not only to judges appointed under the authority of $s .96$ but also to judges appointed under the authority of s. 101. As such, Federal Court judges are Superior Court judges within the meaning of the term in s. 99(2). Accordingly, s. $8(2)$ of the Federal Court Act is unconstitutional. However, Mr. Justice Grant went on to consider a second argument; namely, whether the provision of s. 8(2) of the Federal Court Act contravenes s. 15(1) of the Charter. He concluded that they did but on a somewhat limited basis. He did not conclude that mandatory retirement per se was violative of s. 15 . Nor did he conclude that providing for differential retirement ages for

34. (1985) 8 C.C.E.L. 13.

35. R.S.C. 1970, c. 10 (2nd supp.). 
judges of different courts contravenes s. 15(1), although, he did note that Mr. Justice Addy had himself served as a judge of the Supreme Court of Ontario before assuming his Federal Court responsibilities. The significance of this is that the retirement age of the judges of the Supreme Court of Ontario is 75 while the retirement age of judges of the Federal Court was 70 , and if the same person could serve in both positions, it would be hard to justify the provision of differential retirement ages for judges of different courts as constituting a reasonable limit under s. 1 of the Charter. In any event, he did not in fact conclude that differential retirement ages of judges of differing courts constitutes a violation of s. 15. What he did conclude was that among Federal Court judges, as members of a single class, there were differential retirement ages. Those Federal Court judges who had already been appointed (to the Exchequer Court) on the creation of the Federal Court in 1971 did not have to retire until age 75 while those judges who were appointed to the Federal Court on or after June 1, 1971 had to retire at age 70 . This differentiation, within a class, constituted age discrimination and was therefore violative of s. 15(1).

Although the issue did not arise directly, what would the result have been if Mr. Justice Grant had concluded that Federal Court judges were not Superior Court justices within the meaning of the term Superior Court in s. 99(2)? Then, of course, there would be no conflict between s. 8(2) of the Federal Court Act and s. 99(2) of the Constitution Act of 1867. Let us further assume however that, at some point in time, all existing Federal Court judges have to retire at age 70 under s. 8(2). Then one has a situation where a federal enactment passed pursuant to s. 101 provides for an age of retirement for certain judges different from that contained in s. 99(2), the latter of which applies to other judges. Would the differential retirement ages between Federal Court judges and provincial Superior Court judges then be the basis of an allegation of age discrimination under s. 15? The answer would depend in part upon whether s. 15 invites a comparison of the differential treatment of persons within a class or among various classes. Mr. Justice Grant feels that one must look to discrimination within a class and not among various classes before any differentiation becomes discriminatory within the meaning of s. 15 . That, it is submitted, was the approach of the Supreme Court of Canada in the Lavell case and would not be acceptable under the expansive wording of $s .15$. One is reminded of the words of Mr. Justice Strayer, also of the Federal Court, in the case of Smith, Kline \& French Lab. Ltd. v. A. G. of Canada ${ }^{36}$ where he states:

One must therefore seek criteria to aid in determining whether a legislative distinction creates an inequality which is discriminatory, taking "discrimination" to mean the kind of distinction prohibited by s-s. 15(1). It would not, I think, be appropriate to rely solely on tests commonly used with respect to the interpretation of para. 1(b) of the Canadian Bill of Rights, having regard to the more narrow scope of that provision and the statutory nature of the instrument in which it was found.... I would respectfully observe that in my view there is no magic in the concept of a "class": it has no definition, provides no standard, but is merely a subjective concept. It can therefore not, by itself, be a basis for determining, when a "class" is somehow created or divided legislatively, that discrimination exists. . . . [I]f a certain number of people in society are treated differently there should be a rational basis for distinguishing between them and the rest of society. 
If $\mathrm{Mr}$. Justice Strayer is correct and there is no magic in the concept of "class", we could have a situation, in a case similar to $A d d y$, where a s. 15 argument is based upon discrimination arising out of other, non-Charter, sections of the Constitution. As was pointed out earlier, in that circumstance, a Court would have to utilize the various rules and principles of constitutional adjudication and statutory interpretation in order to resolve the matter. 